Contents lists available at Џournal IICET

JPPI (Jurnal Penelitian Pendidikan Indonesia)

ISSN: 2502-8103 (Print) ISSN: 2477-8524 (Electronic)

\title{
Work systems of persons with disabilities in the company
}

\author{
Imas Diana Aprilia*), Prima Dea Pangestu \\ Universitas Pendidikan Indonesia, Bandung, Indonesia
}

\begin{tabular}{l} 
Article Info \\
Article history: \\
Received Jun $25^{\text {th }}, 2021$ \\
Revised Jul $21^{\text {st }}, 2021$ \\
Accepted Aug $25^{\text {th }}, 2021$ \\
\hline
\end{tabular}

\section{Keyword:}

Work system

Person with disabilities

\begin{abstract}
The absence of an integrative work pattern between schools, companies and the government is a major obstacle for the employment of people with disabilities. Hence, there is need to create adequate partnerships between these stakeholders in the form of systematic and integrated work system and structure. The purpose of this study is to formulate a work system of people with disabilities in the company. A qualitative approach with descriptive methods was used involving four participants, consisting of a principal and a skill teacher at a special school for deaf children, a Head of the Human Research Development (HRD) Division in a Company X, and a Head of the Department of Manpower in Bandung. Data digging is done through interviews, observation and documentation studies. The study consist of three stages, including 1) Assessment of field needs, 2) System Formulation, and 3) Execution Tests. Subsequently, the outcome is used to produce a guideline of Work System for People with Disabilities in Companies, comprising the assessment needs of Schools, Companies and the Manpower Office, alongside Work Principles and Mechanisms, as well as Evaluation. The results is the stakeholders reached an agreement on the value of meaningfulness as a guide. Effective referencing enables relevant parties to work together towards implementation, consistently in an effort to fulfill the individuals' independence while working.
\end{abstract}

(C) 2021 The Authors. Published by IICET.

This is an open access article under the CC BY-NC-SA license (https://creativecommons.org/licenses/by-nc-sa/4.0

\section{Corresponding Author:}

Imas Diana Aprilia,

Universitas Pendidikan Indonesia, Bandung

Email: imasdiana@upi.edu

\section{Introduction}

Disability is a crucial issue that touches many lives in Indonesia. The estimated number of persons with disabilities in Indonesia is $12.15 \%$ of the population or nearly 30 million people. From these data, the number of people with disabilities who participate in the labor market is very low at only $51.12 \%$, when compared to non-disabled persons who reach $70.40 \%$ (Hanadia, 2019). Malaysians with disabilities have significantly higher unemployment rates when compared to their non-disabled peers (Ang, M. C., 2017).The low absorption capacity of people with disabilities to enter the labor market in several companies is allegedly due to the low level of education and discrimination by employers when recruiting employees with disabilities (Cook, 2006 in Halimatussadiah, et al, 2017; Susiana \& Wardah, 2019; Arzul, H. F., dkk, 2019). Fuller (2010) stated that there are three remarkable obstacles related to opportunities for people with disabilities, community prejudice, negative perceptions, and limited company funds in providing access for employees with disabilities. The most common concern among employers is that the belief that Person with Disabilities (PWDs) cannot do the job and are thus perceived as "risky hires."(Ang, M. C., 2017). Meanwhile, Hernandez, et al (2012) stated 
that the lack of understanding of business actors regarding the potential and benefits of employing workers with disabilities raises doubts about business actors in making decisions to recruit disabled people. Lack of work experience, transportation problems, and program engagement issues represented common barriers for both youth with developmental disabilities $(53,36$, and 25\%) and youth with psychiatric disabilities (20, 33, and 26\%). (Noel, V.A., 2017). Companies experience a dilemma in finding qualified employees with disabilities to work in their company (Pangestu, et al 2018; Ang, M.C., 2017). The company especially considers the work productivity of people with disabilities to be very low compared to those of non-disabled persons. They have to compete with non-disabled people in their work which can have an influence on the quality of work according to the competence of disabled people (Yusof, et al, 2015). They work for low paying jobs and are also less likely to get promoted. (Utami, W. K., 2019). Therefore, most of the people with disabilities who work only hold positions as entry-level workers, laborers and seasonal workers (Angela, 2014). From such observations, more employment opportunities for people with disabilities in Indonesia are available in the service sector such as services and retail, while in the industrial sector it is still minimal (Pangestu, 2018). Disabled people can be employed in occupational activity centers, in supported employment enterprises and on the opened labor market (Jasiak \&Królak, 2018). In Malaysia it was figured out that they are still lacking in the workplace compared to ordinary employees (Guenther, et al, 2008). Although the law in Malaysia has a number of advantages and opportunities for PWDs to gain access to the labor market, there is still discrimination and companies lack information about their disability which affects their recruitment as employees. As a result, these workers with disabilities, despite completing their education at the secondary and senior levels, seem to be unable to find jobs (Guenther et al., 2008). On the Malaysian front, employers are more likely to hire migrant workers than hiring PWDs to address the skills shortages issues in the manufacturing, services, construction and plantation sectors (Ang, M.C., 2017).

The Government of Indonesia seeks to fulfill the rights of PWDs. Law Number 8 of 2016 concerning PWDs Article 11 concerning the Rights of PWDs states that every person with disability has equal rights and opportunities in work, entrepreneurship and cooperatives. Furthermore, in article 45 it is explained that; "The Government and Regional Governments are required to ensure a fair and non-discriminatory process of recruitment, acceptance, job training, job placement, job continuity, and career development for PWDs". Employment opportunities for workers with disabilities are also recognized in Article 52 paragraph 1, which states that the government, regional governments, Badan Usaha Milik Negara (BUMN), and Badan Usaha Milik Daerah (BUMD) are required to employ at least $2 \%$ of people with disabilities from the total number of employees or workers. The second paragraph reads, private companies are required to employ at least $1 \%$ of PWDs from the total number of employees or workers. While in Japan, employment of PWDs has mainly been promoted via the employment quota system in Japan, based on the Act on Employment Promotion etc. of Persons with Disabilities. This system (the "employment quota approach") obliges employers to employ persons with disabilities at or above a predetermined ratio. It is further emphasized that Japan is attempting to create unique legislation on employment of persons with disabilities by opting to maintain the existing employment quota approach while embedding the discrimination prohibition approach within it (Hasegawa, 2015).

The government has issued a Circular Letter of the Minister of Manpower and Transmigration Number 01.KP.01.15.2002 on Job Placement of Workers with Disabilities in companies which mandates every head of the Manpower and Transmigration Office to socialize the Law on PWDs and other related laws and regulations. the rights of persons with disabilities to work as an effort to place workers with disabilities in companies, and mandated to collect data on companies that employ persons with disabilities every 3 (three) months and report the results of the data collection to the Minister of Manpower and Transmigration, Directorate General of Binalatpedagri. Efforts to socialize these laws and regulations do not seem to have been properly conducted by local governments. The reality on the ground is that the existing local regulations (PERDA) is still inadequate, there is no task force or conference that accommodates the work system for PWDs and the dissemination on information about job fairs has not been incessant (Pangestu, 2018). This shall be a tight consideration for the Manpower Office to be more optimal in completing its main tasks and functions, as revealed from the Bandung City Information and Documentation Management Officer (PPID) (2017) that the Manpower Office is required a technical guide and legalization basis such as policy formulation, administration of government affairs and public services, development and implementation in the field of training and work productivity, as well as the implementation of other tasks from regional leaders.

This has drawn broad attention and become a central topic that the school's efforts in preparing students with disabilities to work have implemented vocational skills programs through intracurricular, extracurricular, and internship activities in several companies (Permana, et al, 2018; Pangestu, 2019; Prihatin, et al, 2019; Aprilia, ID, 2020). However, these efforts have not been able to meet the achievements of the school's vision in achieving student independence. The absence of certified skilled teachers and the lack of supporting 
infrastructure, the absence of equal partnership between schools and companies, companies are less involved in the process of training, mentoring, job distribution and recruitment for student apprentices (Pangestu, 2018; Aprilia, ID, 2020). Regarding cooperation between schools and companies, Subang Special school West Java seems to be able to channel students into internships and work in several companies and collaborates with several home industries (home industries) in an effort to develop entrepreneurship (Permana, J., et al, 2018, Prihatin, et al, 2019). Meanwhile in Brazil, there is a collaborative program between companies and schools in preparing for disabilities, called "Workplace Adaptation". Within such formulated program, there is a prior assessment of jobs in companies with disabilities, hence the duties that will be done by disabled people is adjusted to their abilities. Therefore, disability is not burdened by the demands of the company (Guimaraes, et al, 2015). In Malaysia, pre-employment for youth with disabilities acquire job skills through a government-run technical vocational education and training system as required by employers. With this preparation and cooperation, it has an impact on good performance in the company (Yusof, et al, 2015, p. 112). The government in Malaysia also formulates comprehensive national education regulations and policies and ensures that these policies are actually realized and persons with disabilities may receive the fulfillment of their rights to work, by initially providing vocational education and training according to the competencies possessed by each disabled person (Lee, MA, et al, 2011).

Based on the above description, there is also emerging evidence that among companies, schools and the government are still respectively running. Unfortunately, schools supposed to prepare people with disabilities for even entry-level work in companies, in fact, are still running alone without any cooperation with companies, both to see needs in the field and in job distribution. The company is also still having difficulty complying with government policies regarding the obligation to accept disabled employees, because of the difficulty in finding disabled employees who match the qualifications and competencies of the company. Cooperation between schools and companies is certainly necessary to overcome these various matters, which in this case cannot be separated from the monitoring from the Government regarding the certainty of the realization of the formulated policies. Thus, put forward a proposal to such issues, we need a system that can connect cooperation among companies, schools and the government, thus people with disabilities can fulfill their rights to work in companies and are able to overcome various barriers while working at the company.

\section{Method}

This study used a qualitative approach with a descriptive method. The participants of this study were four people, consisting of a principal and a skill teacher at a special school for deaf children, a Head of the Human Research Development (HRD) Division in Company X, and a Head of the Manpower Office of Bandung City. Data digging was carried out through interviews with school principals, teachers, HRD head division, and the Head of the Manpower Office. Observations were made at schools and companies, and documentation analysis on supporting documents. This research starts from the initial data collection phase through a preliminary study (field needs assessment) which examines the objective conditions regarding the needs of schools, companies and related agencies. The second phase is the formulation of the work system for persons with disabilities in the Company. The researchers conduct an analysis by considering the results of the assessment, to find out the linkages and integration among schools, companies and the Manpower Office hence they can produce a work pattern for people with disabilities in the company. Furthermore, in order to highlight the feasibility of the formulation of the system, a validation process was carried out through a Focus Group Discussion (FGD). The data collected were analyzed through the data reduction, data display, and conclusion or verification.

\section{Findings and Discussion}

The current research interests focus on formulating a work system for people with disabilities in the workplace. This research-based paper was conducted in three stages; 1) Field needs assessment, 2) System Formulation, 3) System Implementation Test. The present study has resulted in Code of working system on disability in the workplace, which contains needs assessment of schools, companies, and the Manpower Agency; Principles of Employing on Disabled People in the workplace; Working Mechanism of PWDs; and Evaluation on Working System for PWDs in the workplace.

\section{Field Needs Assessment}

Analysis of field needs is prepared based on a study of the objective conditions of school, company, and related agencies. Aspects revealed from the school component, called assessment and planning, vocational skills learned, school support, and parental support. Component aspects of the company include employee recruitment and selection, employee socialization, and employee development and training. Component 
Aspects of the Manpower Agency comprise the formulation of technical policies, administration of government affairs and public services, development and implementation.

\section{School objective conditions}

Based on results obtained in this line of interviews with teachers, on the aspects of assessment and planning, teachers conduct vocational assessments at the beginning of the school year. Vocational planning on learning is not entirely based on the potential and needs of students, however it is based on the skills of teachers and facilities possessed by the school. The teachers have also declared that the data obtained from the parents were very limited due to the refusal and closed attitude of the parents in providing the required data. From the results of observations and documentation studies, it is revealed that in the aspect of providing vocational skills, teachers are simply more dominant in providing hard skills than soft skills and the integration on both skills is less visible. The teachers have also admitted that there is a significant reluctance from parents to continue vocational learning for their children at home. In connection with this, the results of observations and interviews with school principals regarding school support were figured out that the provision of supporting tools and media facilities was inadequate and there was a lack of skilled teachers in utilizing these facilities. For such obvious reason, the school is especially necessary to accomplish internship in the workplace and work training centers. Efforts that shall be constructed by schools are to conduct career maturity assessments for students through joining parents involvement (Permana, 2018). Schools are also necessary to prepare their teachers to have special abilities and skills both hard skills and soft skills in depth. Exploration and optimization of material deepening and vocational training of hard skills and soft skills are especially valuable for teachers, hence the attainment of skills mastery on students is balanced and integrated (Aprilia, 2020). Schools are necessary to cooperate with the business world in providing training to skilled teachers and shall be proactive in providing information on job vacancies and distributing job for students as well as record students who have been accepted to work in the workplace.

\section{Objective conditions of the Company}

Based on results obtained in this line of interviews with the head of Human Resource Development, during the process of recruitment and selection of employees, the company definitely has difficulty in finding information about people with disabilities who have the ability to work. Likewise, during employee socialization, not all employees are able to accept the conditions of people with disabilities and accessibility in company that are not yet accessible to the conditions of people with disabilities. In the aspect of employees development and training, they have figured out difficultly to survive with the conditions and demands of the company, even though the company provides the widest opportunity for development. Based on these obvious matters, companies shall conduct the following recommendations include open recruitment for people with disabilities through various information media such as social media, dissemination of recruitment information to Special Schools and disability NGOs, cooperating in providing internships, providing training and visits to schools, conducting need assessment to determine the placement for PWDs according to their skills, and regular data reporting on employees with disabilities.

\section{Objective condition of the Manpower Agency}

Based on the results of interviews with the head of Manpower Agency, it was found that in the technical aspect of policy formulation, the Local Government regulations (PERDA) that has been made has not received compliance with Law No. 8 of 2016. The company does not have valid data on the number of employees with disabilities. The Manpower Agency or labor office has also not actively disseminated information on job market vacancies that can be utilized by prospective employees with disabilities, thus the participation of applicants with disabilities is still at its minimal scale and there are not many trainings conducted. Based on these obvious conditions, the Manpower Agencies are necessary to form the preparation of a new local regulation (PERDA) which is more adapted to Law No. 8 of 2016. The use of the right strategy in disseminating the Perda that will be compiled, is adjusted to the conditions of the Company. Furthermore, the Manpower Agency is required to collect data on people with disabilities who work in companies and disseminate information related to job vacancies involving people with disabilities. The establishment of a Forum or Task Force that specifically implements programs related to people with disabilities, especially in the field of work as a provider and distributor of labor. This shall receive considerable attention for the Manpower Agency to be most advantageous in completing its main tasks and functions, as revealed from the Bandung City Information and Documentation Management Officer (PPID) (2017) that the Manpower Agency is necessary to conduct a technical guide and a basis for legalization such as policy formulation, administration of government affairs and public services, development and implementation in the field of training and work productivity, as well as the implementation of other tasks from the regional leadership. The policy in fulfilling the rights of people with disabilities in enhancing employment opportunities is to recommend people with disabilities to companies and provide skills training for people with disabilities (Arzul, H. F., et al, 2019). 


\section{Work principle}

Based on the results of the assessment analysis, there are several general and specific principles of the working system of PWDs in the company. First, conduct a job assessment regarding the type of work and field of interest to the children. For students with special needs, of course, must consider the ability of these students with the type of work that can be mastered by them, including cognitive, audio, visual, audio visual, tactile, and kinesthetic motor involvement, and is carried out continuously and repeatedly, and which does not require high mobility. Children with special needs are required to have independence and skills to face the world of work (Hidayat et al., 2020). Second, well-done preparation in hard skills and soft skills according to the child's field of interest. Hard skills includes cognitive, audio, visual, audio visual, tactile, and kinesthetic. Soft skills includes independence, responsibility, commitment, socialization, as needed. The need for a balance of hard skills and soft skills is in line with the opinion of Levinson \& Palmer (2016) which states that specific skills (hard skills and soft skills) are needed to survive in the workplace and in society and need to be taught explicitly. Third, career maturation through an internship program in accordance with the child's field of interest. Career maturity is required for environmental adaptation and mobility. Career maturation that can be done is by helping to socialize the form of communication used, flexible assistance during internships with teacher supervision. Fourth, training regarding the search for job vacancies for students to the preparation stage for applying for jobs. Briefing for finding job vacancies in schools, the Department of Labour, TV and social media. Application stage training in preparing documents, interviews and psychological tests orally and in writing, attitude and appearance. Fifth, conduct a prior need assessment before placing a job position. Inform and socialize the abilities, disabilities and needs of employees with disabilities in several job position options to be occupied. Adjusting workstations to delegated tasks, medical care and activities for rehabilitation of disabled people (Jasiak \&Królak, 2018). Sixth, provide a training period to adapt and socialize with the work environment. Environmental adaptation for adjustment in mobility. Adaptation between disabled employees and environment in the communication usage. Adjustment of the workplace and existing infrastructure within the company. Adaptation to the new environment and socialization for approaches in getting along in the work environment. The proposal of improvements in the organization of work of people with disabilities are training courses organized for employees and employers. (Jasiak \&Królak, 2018).

\section{Work Mechanism}

With regard to this issue, the work system for PWDs is carried out through three stages, the preparation stage, the implementation stage, and the evaluation stage. The preparation stage is a collaboration or partnership among the school and the company and parents. The final goal is that students can master both hard skills and soft skills. In the implementation stage, there is a more synergistic collaboration between the company and the Manpower Office in providing information on job vacancies or job exchanges to schools thus students are extremely prepared to enter the workforce. At this implementation stage, the company conducts recruitment and carries out a need assessment position as well as the adaptation and socialization process. Evaluation stage, at this stage, the Manpower Office either monitors or supervises companies in employing employees with disabilities and collects data on employees with disabilities and companies. The efforts of the Manpower Office are manifested in the formulation of Local Regulations (PERDA) and the formation of groups or forums. The schematic of the workflow mechanism is described in the following Figure 1.

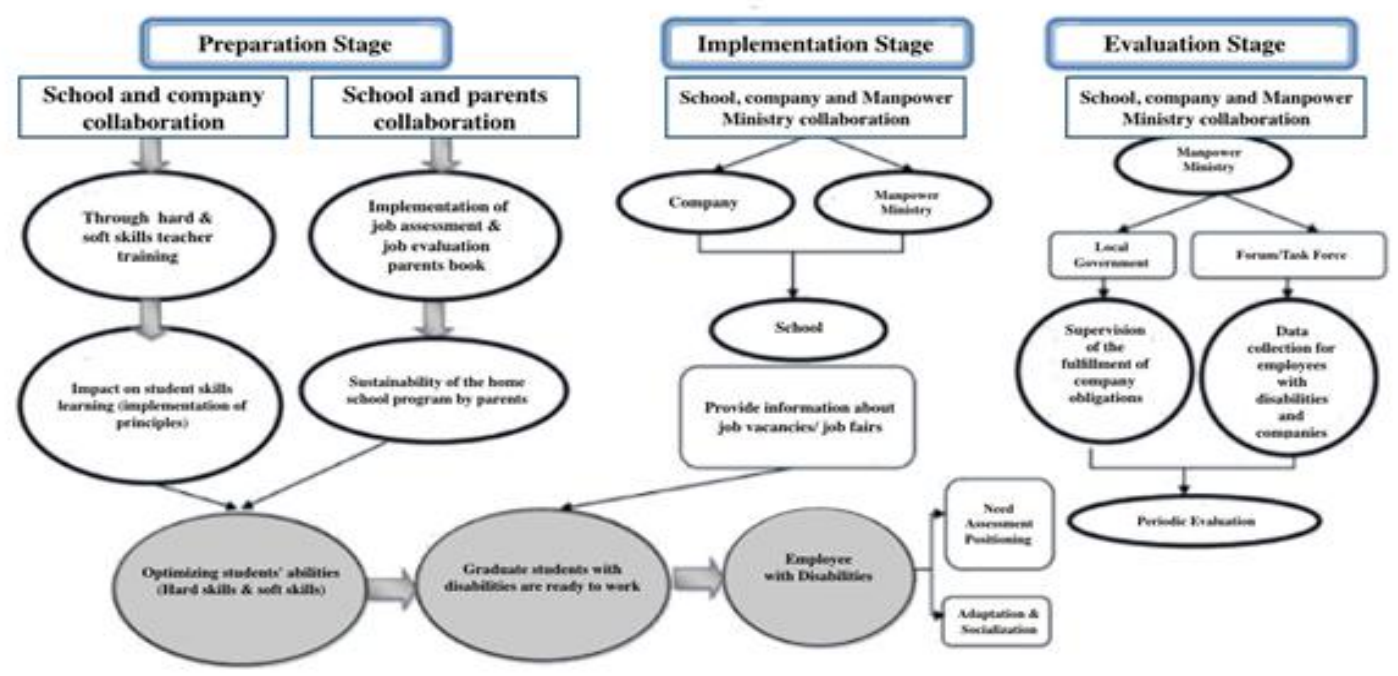

Figure 1. Mechanism on Work System for Persons with Disabilities in the Company 


\section{Evaluation on Work System for Persons with Disabilities in the Company}

Based on the determination of the components, principles and mechanisms of the working system of persons with disabilities in the company, then the indicators or aspects or sub-aspects assessed are for school components are competence of teachers who have received training, skills learning carried out, internship activities carried out, job vacancy training activities carried out, and data for graduates with disabilities who are working. The evaluation aspects for the company components are data on employees with disabilities in the company, performance of employees with disabilities in the company, career development of employees with disabilities in the company, problems in the employment of employees with disabilities in the company. Components of the labor department are data on persons with disabilities who work in the company, data on companies that have employed persons with disabilities, and information on job vacancies and job fairs for persons with disabilities. For parents, evaluations that can be done are children's independence at work, children's responsibilities towards work tasks, discipline of children at workplace, and resilience of children in pursuing work.

\section{Results and Discussions}

The implementation of the assessment is not entirely based on the potential and needs of the students, yet it relies on the ability of the teachers and the facilities they own, describing the assessment process that is less comprehensive. Unclear data on students' conditions may influence decisions to plan training and/or education tailored to the realities of the potential and barriers of persons with disabilities and may ultimately result in students' skills to make a successful transition from school to work and community life (Levinson \& Palmer, 2016) and help set realistic work and independent life goals for students (Chryssolouris, G., et al, 2016). For such obvious reason, it is highly necessary to conduct an assessment beforehand regarding jobs in companies with disabilities, thus the duties that will be performed by people with disabilities is adjusted to their abilities (Guimaraes, et al, 2015). An assessment that begins with the process of absorbing aspirations, coordinating, and capturing internal and external opportunities will eagerly anticipate the school resistance to the employment of their students. (Prihatin, et al, 2019).

Furthermore, to investigate the matter, it is related to addressing skills for students with disabilities to take part in internships in the Business Activities or Global Industry. This training is a necessity, there is now considerable evidence that prospective apprentices have different educational experiences before, thus demanding a training that directs them to work effectively and productively (Chryssolouris, G., et al, 2016). The recruitment of interns is of course tailored to the analysis of manpower needs (number) and the job analysis includes the type of knowledge, competence or skills required, such as the type of work that students with disabilities can do. With such obvious needs analysis, schools are effectively able to link their students into internships and work in several companies and proactively collaborate with several home industries in an effort to develop entrepreneurship (Permana, J., et al, 2018). Previously, apprentices were included in basic skills training for approximately three months (Prihatin, et al, 2019).

An alternative that companies can do in seeking information about persons with disabilities who have the ability to work (recruitment) is to cooperate with the Department of Manpower. This recruitment and selection process is mainly important to ensure fairness and equal treatment of all candidates (Mullins, 2001, p. 275). Moreover, the Manpower Office must be able to strengthen regulations and legislation, carry out its main tasks and functions in a comprehensive and accommodating manner. After going through the recruitment and selection process, it is important to conduct socialization to help new employees get to know the environment, adapt to their new roles, and to build good professional relationships with other employees (Mullins, 2001, p. 279). Companies can conduct trials of disabled workers by placing them in supporting jobs and carrying out development stages by increasing the number of disabled workers to meet the quota of the number of employees and expanding the recruitment area (Prihatin, et al, 2019). Furthermore, to increase productivity and a comfortable work environment, it is necessary to more increase awareness and openness from managers and employees, communication and friendly relations as well as accessibility for persons with disabilities. Use of sign language, display of simple text, Braille, embossed communication, large print, easily accessible and written multimedia, audio, human-reader augmentative alternatives and other forms, means and formats of additional and alternative communication, including information technology and accessible communication (Pangestu, 2018). This is in line with the description of Better Work Indonesia (2012) which is "Raising awareness of managers and employees before the process of recruiting persons with disabilities will be very advantageous".

The low absorption capacity of people with disabilities in companies, as well as the complexity of the company's high competitiveness demands that are difficult to achieve, of course, the involvement of companies in empowering students with disabilities is expected to encourage variations in the provision of 
suitable programs for students with disabilities; hence it is to facilitate vocational planning that will allow a student to make a successful adjusment to work. For instance, like what the SLB Negeri Subang did, among other programs that the company could develop, entrepreneurship programs for students with disabilities are still possible (Permana, et al, 2018). Through corporate social responsibility (CSR) funds directed at empowering persons with disabilities in the entrepreneurial sector, it is highly expected to create greater success because within its implementation it can involve CSR distributing companies as companions or mentors (Prihatin, et al, 2019). The participation of the private sector in empowering students with disabilities is expected to overcome various obstacles faced by the Government. The synergy of schools, government, the workplace and the community will address an optimal impact if the role of the principal has qualified entrepreneurial competence; and therefore they could identify themselves to utilize all available resources based on the right cost benefit analysis in managing life skills education for students with disabilities.

\section{Conclusions}

Based on results obtained in this line of research, the present study produces a practical guidance to the Work System for PWDs in Companies, which contains an assessment of the needs of schools, companies, and the Department of Manpower; Principles of Working with PWDs in the Company; Working Mechanism of PWDs in the Company; and Evaluation of Work System for PWDs in the Company. Furthermore, based on results obtained in this line of implementation test, confirmation and agreement were obtained from the stakeholders that the manual for working systems for PWDs with disabilities in the company has the value of meaningfulness, legibility, and feasibility as a guide. With the references and signs in this manual for the work system for PWDs, related parties can synergize and commit to implementing the work system for PWDs consistently as an effort to fulfill the independence of PWDs in working in the company.

\section{References}

Ang, M. C. (2017). The challenges and benefits of employing persons with disabilities: The japanese multinational corporations' perspective. International Journal of Innovation, Management and Technology, 8(5), 359-366.

Angela, B. M. (2015). Employment of persons with disabilities. Procedia-Social and Behavioral Sciences, 191, 979-983.

Aprilia, I. D., \& Soendari, T. (2020, October). The readiness of special school in developing independence of students with special needs through vocational skills. In Borderless Education as a Challenge in the 5.0 Society: Proceedings of the 3rd International Conference on Educational Sciences (ICES 2019), November 7, 2019, Bandung, Indonesia (p. 245). Routledge.

Arzul, H. F., Khaidir, A., \& Mubarak, A. (2019). Peranan Dinas Tenaga Kerja dan Perindustrian dalam Meningkatkan Kesempatan Kerja Bagi Penyandang Disabilitas. JESS (Journal of Education on Social Science), 3(2), 135-143.

Better Work Indonesia. (2012). Pedoman Untuk Perusahaan:Mempekerjakan Penyandang Disabilitas.[Online]Tersedia:https://betterwork.org/indonesia/wpcontent/uploads/Guidelines_Ind_011212.pdf.

Blázquez, M., \& Malo, M. Á. (2005). Educational mismatch and labour mobility of people with disabilities: the Spanish case. Revista de Economía Laboral., 2(1), 31-55.

Chryssolouris, G., Mavrikios, D., \& Rentzos, L. (2016). The teaching factory: a manufacturing education paradigm. Procedia Cirp, 57, 44-48.

Fuller, S. K. (2010). Employment for the developmentally disabled via one-stop centers (Doctoral dissertation, Capella University).

Guenther, J., Falk, I., \& Arnott, A. (2008). The role of vocational education and training in welfare to work. National Centre for Vocational Education Research.

Guimarães, B., Martins, L. B., \& Junior, B. B. (2015). Workplace adaptation of people with disabilities in the construction industry. Procedia Manufacturing, 3, 1832-1837.

Halimatussadiah, A., Nuryakin, C., Muchtar, P. A., Bella, A., \& Rizal, H. (2017). Mapping persons with disabilities (PWDs) in Indonesia labor market. Economics and Finance in Indonesia, 63(2), 126-149.

Hanadia, M. P. (2019). Pola Komunikasi Para Pegawai Penyandang Disabilitas Fisik (Studi Deskriptif Kualitatif Komunikasi Bahasa Isyarat Para Pramusaji Penyandang Tunarungu Dalam Memberikan Pelayanan Dan Informasi Kepada Pelanggan Di Deaf Cafe Fingertalk) (Bachelor thesis, Universitas Bhayangkara Jakarta Raya).

Hasegawa, T. (2015). Reasonable accommodation for persons with disabilities in Japan. Japan Labor Review, 12(1), 21-37. 
Hernandez, B., Chen, B., Araten-Bergman, T., Levy, J., Kramer, M., \& Rimmerman, A. (2012). Workers with disabilities: Exploring the hiring intentions of nonprofit and for-profit employers. Employee Responsibilities and Rights Journal, 24(4), 237-249.

Hidayat, D. S., Rahmat, C., Fattah, N., Rochyadi, E., Nandiyanto, A., \& Maryanti, R. (2020). Understanding Archimedes law: What the best teaching strategies for vocational high school students with hearing impairment. Journal of Technical Education and Training, 12(1).

Jasiak, A., \& Królak, P. (2018). The Importance of Work for People with Disabilities and Evaluation Imposed Obligations of Employers. Ergonomics For People With Disabilities, Warsaw, Sciendo publ, 227-238.

Kementerian Ketenagakerjaan Republik Indonesia. (online) tersedia : TEMPO.CO., diakses tanggal 24 Februari 2021

Keputusan Menteri Tenaga Kerja RI No. KEP-205/MEN/1999 tentang Pelatihan Kerja dan Penempatan Tenaga Kerja Penyandang Cacat

Lee, M. N., Abdullah, Y., \& Mey, S. C. (2011). Employment of People with Disabilities in Malaysia: Drivers and Inhibitors. International Journal of Special Education, 26(1), 112-124.

Levinson, E. M. \& Palmer, E. J. (2016). Preparing students with disabilities for school-to-work transition and post-school life. Principal Leadership, 5(8), 11- 15.

Mullins, L. J. (2001). Hospitality management and organisational behaviour. Pearson Education.

Noel, V. A., Oulvey, E., Drake, R. E., \& Bond, G. R. (2017). Barriers to employment for transition-age youth with developmental and psychiatric disabilities. Administration and Policy in Mental Health and Mental Health Services Research, 44(3), 354-358.

Pangestu, P. D. (2018). SISTEM BEKERJA PENYANDANG DISABILITAS DI PERUSAHAAN (Master Thesis, Universitas Pendidikan Indonesia).

Pangestu, P. D., \& Aprilia, I. D. (2018). The Analysis of Problems Causing the Inhibitors of Deaf's Work in the Company. Journal of ICSAR, 2(2), 134-138.

Permana, J., Prihatin, E., \& Aprilia, I. D. (2018). Manajemen Pendidikan Life Skill Berbasis Vokasional Pada Siswa Disabilitas Untuk Siap Bekerja. Laporan Penelitian https://doi.org/10.1016/j.palaco, 2007.10.013

PPID (Pejabat Pengelola Informasi dan Dokumentasi ) Kota Bandung. (2016). Data Perusahaan di Kota Bandung. [Online] Tersedia : https://ppid.bandung.go.id/ Diakses tanggal 18 Oktober 2017

Prihatin, E., Aprilia, I. D., \& Permana, J. (2019). Model Manajemen Pendidikan Life Skill pada Anak Berkebutuhan Khusus. Jurnal Penelitian Pendidikan, 18(3), 306-317.

Susiana, S., \& Wardah, W. (2019). Pemenuhan hak penyandang disabilitas dalam mendapatkan pekerjaan di BUMN. Law Reform, 15(2), 225-238.

Surat Edaran Menteri Tenaga Kerja dan Transmigrasi No.: 01.KP.01.15.2002 tentang Penempatan Tenaga Kerja Penyandang Cacat di Perusahaan

Undang-undang Nomor 8 Tahun 2016 Tentang Penyandang Disabilitas

Utami, W. K. (2019). Studi Perbandingan Perlindungan Hak Penyandang Disabilitas Di Indonesia Dan Wilayah Asia Tenggara. Jurnal Polinter: Kajian Politik Dan Hubungan Internasional, 4(2), 36-47.

Yusof, A. M., Ali, M. M., \& Salleh, A. M. (2014). Employability of vocational school leavers with disabilities. Procedia-Social and Behavioral Sciences, 112, 1064-1069. 